\title{
Land Judging and Homesite Evaluation - Pointers for Coaches and Contest Officials ${ }^{1}$
}

Randy Brown ${ }^{2}$

\section{Introduction}

Through land judging and homesite evaluation programs, young people are introduced to the soil as a basic natural resource, to differences among soils as to their suitabilities for agricultural and non-agricultural uses, and to techniques for the wise use and conservation of soils.

The last major revisions to IFAS Circular 242 (http://edis.ifas.ufl.edu/SS181), "Land Judging and Homesite Evaluation in Florida," by J. H. Herbert, Jr., R. B. Brown, and E. A. Hanlon, Jr. culminated in publication of the current version of the Circular. These changes have led, it is hoped, to improved clarity of procedures for judging Florida's soils and to improved standardization of judging from year to year and from contest to contest around the state.

The purpose of this Fact Sheet, as a revision of an earlier edition of NOTES IN SOIL SCIENCE No. 28 , is to expand upon and clarify several points in Circular 242. The information herein is not to be considered an errata sheet or a correction of the current Circular. Circular 242 should continue to serve as the basic teaching tool and official scoring guide for use in land judging and homesite evaluation activities throughout Florida.

This publication is intended for use by vo-ag teachers, 4-H agents and leaders, Natural Resources Conservation Service personnel, Conservation District officials, and others involved in training contest participants or in conducting contests at the district or state level.

The format and captions of this Fact Sheet follow those of Circular 242.

\section{Land Judging \\ Definitions of Land Characteristics}

\section{Surface Texture}

Some confusion may result from the fact that fine sandy loam and very fine sandy loam are listed in the table, but are not shown in the USDA textural triangle shown in the Circular. Fine sandy loam and very fine sandy loam are variations of sandy loam; they have especially high contents of fine sand and very fine sand-sized particles, respectively. Both are

1. This document is Fact Sheet SL226, a fact sheet of the Soil and Water Science Department, Florida Cooperative Extension Service, Institute of Food and Agricultural Sciences, University of Florida. Original publication date: July 2005. Visit the EDIS Web Site at http://edis.ifas.ufl.edu.

2. Randy Brown, Professor Emeritus, Soil and Water Science Department, Florida Cooperative Extension Service, Institute of Food and Agricultural Sciences, University of Florida, Gainesville, FL 32611-0510.

The Institute of Food and Agricultural Sciences (IFAS) is an Equal Opportunity Institution authorized to provide research, educational information and other services only to individuals and institutions that function with non-discrimination with respect to race, creed, color, religion, age, disability, sex, sexual orientation, marital status, national origin, political opinions or affiliations. U.S. Department of Agriculture, Cooperative Extension Service, University of Florida, IFAS, Florida A. \& M. University Cooperative Extension Program, and Boards of County Commissioners Cooperating. Larry Arrington, Dean 
loamy, although they may differ somewhat from each other in permeability or other behavior.

\section{Permeability}

Soil horizons that are organic (as defined under Surface Texture) should be treated as having rapid permeability unless compaction or some other soil feature gives cause to think otherwise.

\section{Drainage}

As indicated in Circular 242, wetness of a soil is influenced by many factors, including internal drainage, permeability, and depth to the water table. Note that there is a strong correlation between depth to the seasonally high (or "wet-season") water table and the drainage class of a soil. Landscape position is another factor that influences drainage.

It should be emphasized as well that the presence of a spodic horizon in Florida's soils is frequently but not always an indicator of poor drainage. Landscape position and/or other factors can cause a Spodosol to be somewhat poorly drained or drier.

\section{Land Capability Class}

See Table 1 for four additional examples that are not covered in the table of examples in Circular 242.

\section{Soil Taxonomy}

Soil orders are listed alphabetically in Circular 242. It should be understood, however, that there is a protocol for determining the taxonomic classification of a soil. Soils should be keyed out in the following sequence:

- Histosols

- Spodosols

- Oxisols

- Vertisols

- Aridisols

- Ultisols

- Mollisols
- Alfisols

- Inceptisols

- Entisols

For example, a soil that qualifies for the Histosol order should be placed in the Histosols, regardless of whether or not the soil meets any of the requirements of an order or orders further down the list. Similarly, a soil that does not qualify for the Histosols but does qualify for the Spodosols should be called a Spodosol, whether or not the soil has a relatively fine-textured subsoil, and regardless of base saturation. For additional information on this subject, see Soil and Water Science Fact Sheet SL43 (http://edis.ifas.ufl.edu/SS113), "Key to Soil Orders in Florida," by M.E. Collins.

\section{Conservation Practices}

\section{Mechanical}

\section{Number 20. Maintain terraces}

This practice should be used with practice 18 and/or practice 21 . This clarification merely formalizes the interpretation that officials and participants have been making.

\section{Fertilizer and soil amendments}

Contest officials may want to indicate $\mathrm{Mg}$ or $\mathrm{S}$ as deficient, and employ item 33 to meet that deficiency, provided that prior warning is given to the contestants that the appropriate element should be filled in on the blank line for item 33, before the contest.

\section{How to Use the Land Judging Score Card}

Under item 7, it is stated that the official judges will deduct penalty points in Part Two for those practices that have been checked but are incorrect. This is and will continue to be so. There are different ways, however, to achieve a "penalty" and maintain fairness, speed, and accuracy in grading.

One means of grading Part Two is to examine each " $\mathrm{X}$ " that the contestant has made and make a decision (points awarded if the " $\mathrm{X}$ " ought to be there, points deducted if the " $\mathrm{X}$ " ought not to be there) on 
each "X." Table 2 is an example of how a card would be scored using this procedure.

This technique is fair, but can be laborious and confusing for the grader, especially if the grader is new to the job. (By the way, the above technique is used in the machine-grading software employed at the State Contest.)

Another technique (and one that has been used in the past at the National Contest and also at the Florida State Contest) is to divide the practices in Part Two into three groups (Vegetative; Mechanical; and Fertilizer \& Soil Amendments), and grade each group by examining only a given number of the contestant's "X's" that the grader first encounters going down the card. If, for example, there are supposed to be four correct practices in the Vegetative group, the grader examines only the first four of the contestant's "X's" that the grader encounters going down the Vegetative section of a card. If an "X" belongs, it gets the appropriate number of points; if it does not belong, it gets no points. Any of the contestant's "X's" below the first four "X's" encountered are ignored. No points are deducted. The grader then considers the Mechanical section as another group, examining only the number of "X's" in that group that are appropriate, and so on with the Fertilizer \& Soil Amendments group. Examples follow in Tables 3, 4 and 5.

(There are four correct answers in the VEGETATIVE section; therefore the grader examines and grades only the first four of the contestant's answers.)

(There are four correct answers in the MECHANICAL section; therefore the grader examines and grades only the first four of the contestant's answers.)

(There are two correct answers in the FERTILIZER \& SOIL AMENDMENTS section; therefore the grader examines and grades only the first two of the contestant's answers.)

This technique is slightly less precise, but also less laborious and confusing, than the first example. The risk of error by the grader is lower, and a "penalty" is imposed without actually having to deduct points, because excessive checking of boxes hurts the participant. (Contestants might get the idea that, under this system, it would pay to check "X's" liberally in the lower part of each section, because it is less likely that a penalty will be imposed for extra "X's" in the lower part than in the upper. Such practice can be discouraged by grading the cards for some pits from the bottom - i.e., by examining the

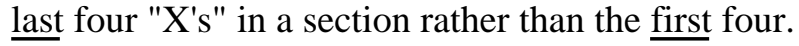
Contest officials need not tell the participants which pits will be graded "from the bottom" and which pits will be graded "from the top." Guessing to beat the system will thus be minimized.)

Note also that the number of points awarded per answer on Part Two of the land judging scorecard is allowed to vary at the discretion of the contest judges.

\section{Conditions of Fields for Land Judging}

Contest officials might want to consider using better itemization of conditions than currently is indicated in the example in Circular 242. Particular emphasis might be given to item 2, as in the example in Table 6:

\section{Homesite Evaluation}

\section{Factors Affecting Limitations}

\section{Shrink-swell}

Organic materials (as defined under Surface texture near the beginning of Circular 242 and under

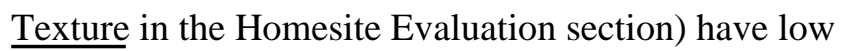
shrink-swell potential. Granted, they are subject to subsidence, but shrink-swell is a different phenomenon from subsidence.

Montmorillonite is one kind of smectite. For contest purposes, the two terms (montmorillonite and smectite) should be considered to be synonymous.

\section{Conditions of Fields for Homesite Evaluation}

As with land judging, careful itemization on the homesite evaluation conditions poster would be helpful both to contest officials and to contest participants, as in the example in Table 7. 


\section{Conclusion}

When there is doubt as to the manner in which soils will be judged officially and/or as to the correct interpretation of guidelines in Circular 242 and in this Fact Sheet, coaches should discuss their concerns with contest officials before the date of a contest, to clear up any possible misunderstandings. If further clarification is needed, phone calls, correspondence, emails and/or in-person visits to Randy Brown in the UF/IFAS Soil and Water Science Department in Gainesville are always welcome.

Randall "Randy" B. Brown, Professor Emeritus, Soil and Water Science Department, 106 Newell, Box 110510, U of Florida, Gainesville, FL 32611-0510; 352-392-1804x344, fax 352-392-3399; http://brown.ifas.ufl.edu; email rbb@ufl.edu 
Table 1.

\begin{tabular}{|cccccccc|}
\hline \hline $\begin{array}{c}\text { SurfaceT } \\
\text { exture }\end{array}$ & $\begin{array}{c}\text { Organic } \\
\text { Matter }\end{array}$ & $\begin{array}{c}\text { Thickness } \\
\text { of } \\
\text { Rooting } \\
\text { Zone }\end{array}$ & Permeability & Slope & Erosion & Drainage & $\begin{array}{c}\text { Land } \\
\text { Capability } \\
\text { Class }\end{array}$ \\
\hline II & I & II & I & II & I & I & II \\
II & I & II & II & II & II & II & III \\
II & I & II & I & IV & IV & I & VI \\
I & I & I & II & IV & IV & IV & VII \\
\hline \hline
\end{tabular}

Table 2.

\begin{tabular}{|c|c|c|c|}
\hline Correct Answer & Points Awarded & Contestant's Answer & Practice \\
\hline \multicolumn{4}{|c|}{ Vegetative } \\
\hline [ ] & & [ ] & 1. \\
\hline [ ] & -3 & {$[X]$} & 2. \\
\hline$[X]$ & & [ ] & 3. \\
\hline [ ] & & [ ] & 4. \\
\hline$[X]$ & +3 & {$[X]$} & 5. \\
\hline$[X]$ & +3 & {$[X]$} & 6. \\
\hline [ ] & & [ ] & 7. \\
\hline [ ] & & [ ] & 8. \\
\hline [ ] & & [ ] & 9. \\
\hline$[X]$ & +3 & {$[X]$} & 10. \\
\hline [ ] & & [ ] & 11. \\
\hline [ ] & & [ ] & 12. \\
\hline [ ] & & [ ] & 13. \\
\hline [ ] & & [ ] & 14. \\
\hline [ ] & & [ ] & 15. \\
\hline [ ] & & [ ] & 16. \\
\hline [ ] & & {$[$ ] } & 17. \\
\hline \multicolumn{4}{|c|}{ Mechanical } \\
\hline$[X]$ & +3 & {$[X]$} & 18. \\
\hline$[X]$ & & [ ] & 19. \\
\hline$[\mathrm{X}]$ & +3 & {$[X]$} & 20. \\
\hline [ ] & & [ ] & 21. \\
\hline$[X]$ & +3 & {$[\mathrm{X}]$} & 22. \\
\hline [ ] & & [ ] & 23. \\
\hline [ ] & & [ ] & 24. \\
\hline [ ] & -3 & {$[\mathrm{X}]$} & 25. \\
\hline [ ] & -3 & {$[\mathrm{X}]$} & 26. \\
\hline \multicolumn{4}{|c|}{ Fertilizer \& Soil Amendments } \\
\hline [ ] & -3 & {$[\mathrm{X}]$} & 27. \\
\hline$[\mathrm{X}]$ & +3 & {$[\mathrm{X}]$} & 28. \\
\hline [ ] & & [ ] & 29. \\
\hline$[\mathrm{X}]$ & +3 & {$[X]$} & 30. \\
\hline [ ] & -3 & {$[X]$} & 31. \\
\hline$[\quad]$ & & {$[1]$} & 32. \\
\hline
\end{tabular}


Table 2.

\begin{tabular}{|c|cccc|}
\hline \hline[] & {[} & 33. \\
& & Score Part II & $\mathbf{9}$ \\
\hline \hline
\end{tabular}

Table 3.

\begin{tabular}{|c|c|c|c|}
\hline Correct Answer & Points Awarded & Contestant's Answer & Practice \\
\hline \multicolumn{4}{|c|}{$\begin{array}{l}\text { Vegetative } \\
\end{array}$} \\
\hline [ ] & & [ ] & 1. \\
\hline [ ] & & {$[X]$} & 2. \\
\hline$[X]$ & & [ ] & 3. \\
\hline [ ] & & [ ] & 4. \\
\hline$[\mathrm{X}]$ & 2 & {$[\mathrm{X}]$} & 5. \\
\hline$[X]$ & 2 & {$[\mathrm{X}]$} & 6. \\
\hline [ ] & & [ ] & 7. \\
\hline [ ] & & [ ] & 8. \\
\hline [ ] & & [ ] & 9. \\
\hline$[\mathrm{X}]$ & 2 & {$[\mathrm{X}]$} & 10. \\
\hline [ ] & & [ ] & 11. \\
\hline [ ] & & [ ] & 12. \\
\hline [ ] & & [ ] & 13. \\
\hline [ ] & & [ ] & 14. \\
\hline [ ] & & [ ] & 15. \\
\hline [ ] & & [ ] & 16. \\
\hline [ ] & & [ ] & 17. \\
\hline
\end{tabular}

Table 4.

\begin{tabular}{|c|c|c|c|}
\hline Correct Answer & Points Awarded & Contestant's Answer & Practice \\
\hline \multicolumn{4}{|c|}{ Mechanical } \\
\hline$[X]$ & 2 & {$[\mathrm{X}]$} & 18. \\
\hline$[X]$ & & [ ] & 19. \\
\hline$[X]$ & 2 & {$[X]$} & 20. \\
\hline [ ] & & [ ] & 21. \\
\hline$[X]$ & 2 & {$[X]$} & 22. \\
\hline [ ] & & [ ] & 23. \\
\hline [ ] & & [ ] & 24. \\
\hline [ ] & & {$[X]$} & 25. \\
\hline [ ] & & {$[X]$} & 26. \\
\hline
\end{tabular}


Table 5.

\begin{tabular}{|c|c|c|c|c|}
\hline Correct Answer & Points Awarded & Contestant's Answer & Practice & \\
\hline \multicolumn{5}{|c|}{ Fertilizer \& Soil Amendments } \\
\hline [ ] & \multirow{7}{*}{2} & {$[\mathrm{X}]$} & 27. & \\
\hline$[X]$ & & {$[X]$} & 28. & \\
\hline [ ] & & [ ] & 29. & \\
\hline$[X]$ & & {$[X]$} & 30. & \\
\hline [ ] & & {$[X]$} & 31. & \\
\hline [ ] & & [ ] & 32. & \\
\hline \multirow[t]{2}{*}{ [ ] } & & [ ] & 33. & \\
\hline & & & Score Part II & 14 \\
\hline
\end{tabular}

Table 6.

CONDITIONS OF FIELDS FOR LAND JUDGING FIELD NO.

Assume that the following interpretations of farm records and soil tests have been made for the crop to be grown:

1. Thickness of the surface soil was

2. Other conditions are:

Base saturation $=$

[...other information (possibly including presence of upslope water problem; wind erosion hazard; range of depths to wet-season water table; compaction problem; etc.) that contest officials deem fair and appropriate to provide...]

3. Pay no attention to current practices on this field.

4. Consider the most intensive use of the land.

5. The crop (will, will not) benefit from reduction of soil acidity.

6. Phosphorus soil test is rated as

7. Potassium soil test is rated as

8. The following nutrients will be deficient for the crop to be grown:

Table 7.

\section{CONDITIONS OF FIELDS FOR HOMESITE EVALUATION FIELD NO.}

1. Thickness of the surface soil was

2. Other conditions are:

[...other information (such as type of clay mineral that is dominant; frequency of flooding; etc.) that contest officials deem fair and appropriate to provide...]

3. Pay no attention to current practices on this field. 